\title{
Idiopathic Orbital Myositis with Pseudosixth Nerve Palsy: The Importance of Neuroimaging
}

Psödoaltıncı Kranyal Sinir Felci ile Gelen İdyopatik Orbital Miyozit Olgusu: Nörogörüntülemenin Önemi

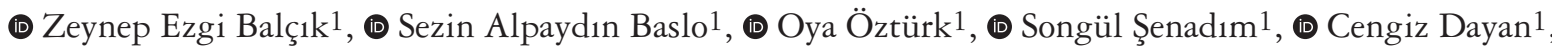
(1) Hatem Hakan Selçuk ${ }^{2}$, (1) Hayrunnisa Dilek Atakl1 ${ }^{1}$

1Bakirkoy Prof. Dr. Mazhar Osman Mental Health and Neurological Diseases Training and Research Hospital, Clinic of Neurology, Istanbul, Turkey

Bakirkoy Dr. Sadi Konuk Training and Research Hospital, Clinic of Neurology, Istanbul, Turkey

Keywords: Orbital myositis, pseudotumor orbita, sixth nerve palsy, magnetic resonance imaging

Anahtar Kelimeler: Orbital miyozit, psödotümör orbita, altıncı sinir felci, manyetik rezonans görüntüleme

Dear Editor,

A 48-year-old female was admitted with a right hemicranial, throbbing headache for 10 days that intensified behind the right eye and horizontal diplopia worsening with right gaze. There was no feature in her medical history and resume. Neurological examination revealed inward deviation of her right eye in primary position and 3-mm abduction failure. There was also a mild right sided proptosis. Fundus examination was normal.

Blood biochemistry tests, complete blood count, thyroid function tests and autoantibodies and glycosylated hemoglobin level were normal. Vasculitic markers (ANA, p-ANCA, c-ANCA, antids-DNA, AMA, ASMA, anti-Scl-70, anti-Jo-1, anti-SSA, anti-SSB), anti-acetylcholine receptor antibody and infectious serologic markers (hepatitis B surface antigen, herpes simplex virus type 1 and type 2 IgM anti-HIV, Brucella, Varicella-Zoster virus IgM, anti-HCV, VDRL-RPR) were negative. Cranial computed tomography and contrast-enhanced magnetic resonance imaging (MRI) were normal. Nerve conduction studies, needle electromyography and repetitive nerve stimulation were normal. Cerebrospinal fluid was acellular and biochemistry was normal. IgG index was within normal ranges (0.37).

Right medial rectus muscle was hypertrophic and isohyperintense in T2, and contrast-enhanced, fat-suppressed T1weighted images (Figure 1A, 1B, 1C, 1D). Myotendinous junction was also involved (Figure 1A, 1B).
With specific orbital MRI findings, our patient was diagnosed as having "idiopathic orbital myositis". Methylprednisolone treatment of $80 \mathrm{mg}$ /day p.o was initiated. Signs and symptoms improved in the first week of treatment and the patient fully recovered in the second week. The steroid dose was tapered gradually, until the lowest maintenance dose was sustained.

"Orbital myositis" is an inflammatory disease that primarily effects extraocular muscles (1). Patients are often in their 30s and females are affected twice as frequently as males. Generally, the medial rectus muscle is unilaterally impaired. Acute-onset painful diplopia is the most frequent presenting symptom. Pain may be exacerbated by ocular movements. Limitation of ocular movements, conjunctival edema and proptosis can be detected in neurological examination. Hypertrophy of impaired extraocular muscle(s) shown by neuroimaging is important for diagnosis. Impaired extraocular muscle is seen as thick and hyperintense in T2-weighted imaging (2). Impairment of the myotendinous junction and tendons distinguishes orbital myositis from thyroid ophthalmopathy. Frequently, the etiology of orbital myositis is unknown. Histopathology of orbital myositis, also known as "idiopathic inflammatory orbital syndrome", reveals mixed inflammation consisting of fibrosis in various degrees, plasma cells, lymphocytes, macrophages, and polymorphonuclear leukocytes (3). Other causes leading to ophthalmoparesis, in particular; primary vascular diseases (e.g., ischemia, hemorrhage, aneurysm or carotid-cavernous fistula of the brain stem), diseases

Address for Correspondence/Yazışma Adresi: Zeynep Ezgi Balçık MD, Bakirkoy Prof. Dr. Mazhar Osman Mental Health and Neurological Diseases Training and Research Hospital, Clinic of Neurology, Istanbul, Turkey

Phone: +90 5054562952 E-mail: zeynepezgi33@hotmail.com ORCID ID: orcid.org/0000-0002-2882-7646

Received/Geliş Tarihi: 05.04.2017 Accepted/Kabul Tarihi: 24.07.2017

${ }^{\circ}$ Copyright 2018 by Turkish Neurological Society

Turkish Journal of Neurology published by Galenos Publishing House. 


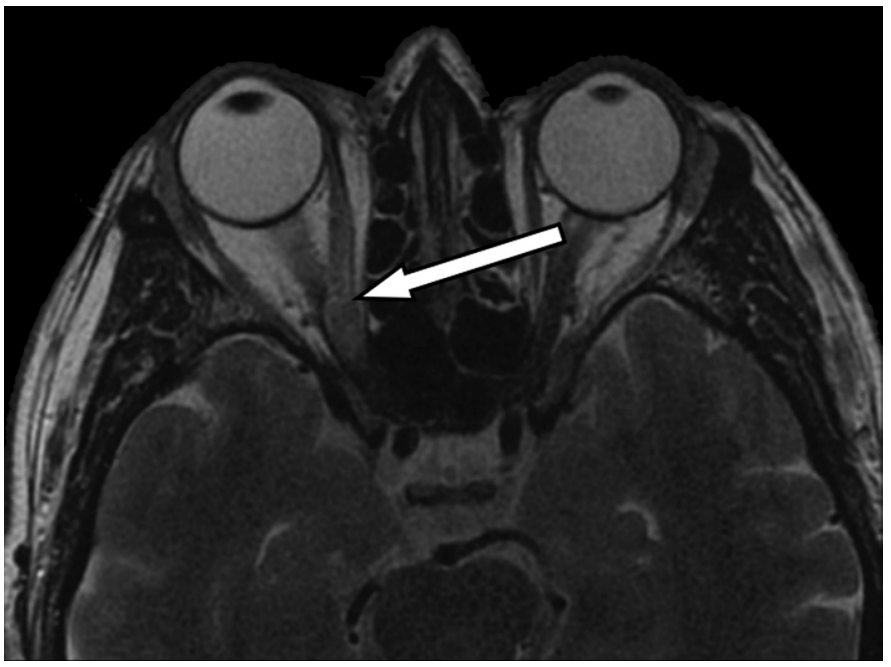

Figure 1. A) Axial T2, arrow: Hypertrophic isointense right medial rectus muscle and tendinous junction

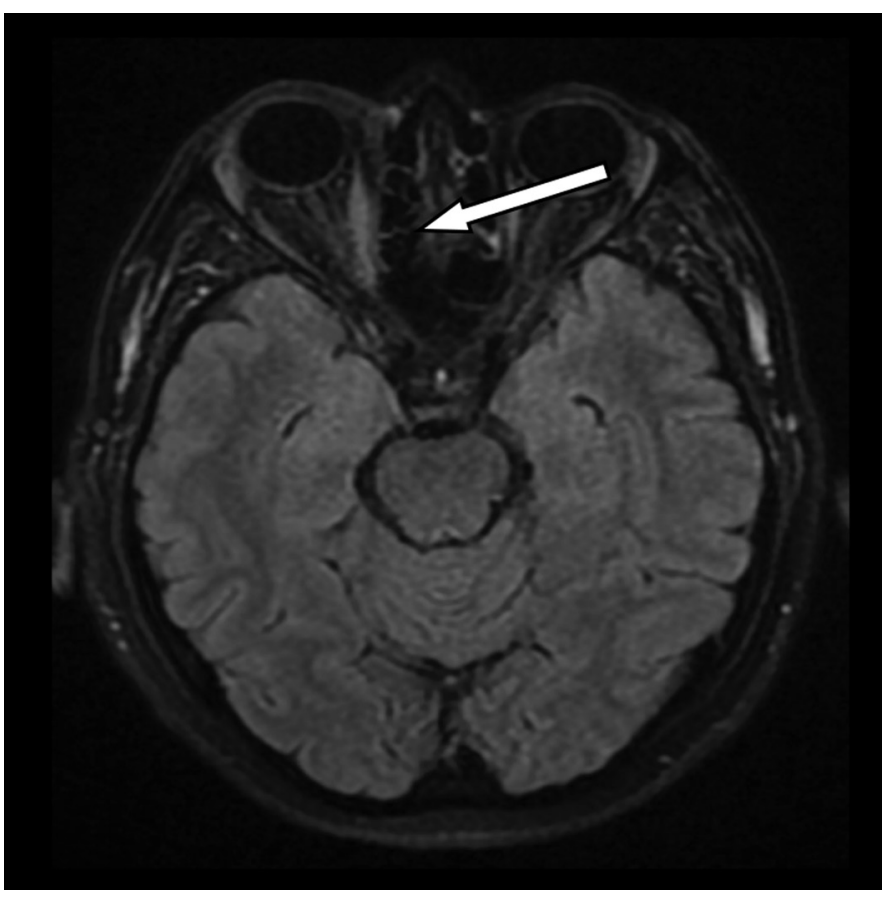

Figure 1. B) Axial FLAIR, arrow: Hyperintense right medial rectus muscle and tendinous junction

with vascular complications such as hypertension and diabetes mellitus, granulomatous or inflammatory disorders of cavernous sinus like thyroid ophthalmopathy and Tolosa-Hunt syndrome, neuromuscular junction disorders such as myasthenia gravis and acute polyneuropathy syndromes like Fisher syndrome should be kept in mind in differential diagnosis (4). Systemic corticosteroids are used in treatment of orbital myositis. Non-steroidal immunosuppressants

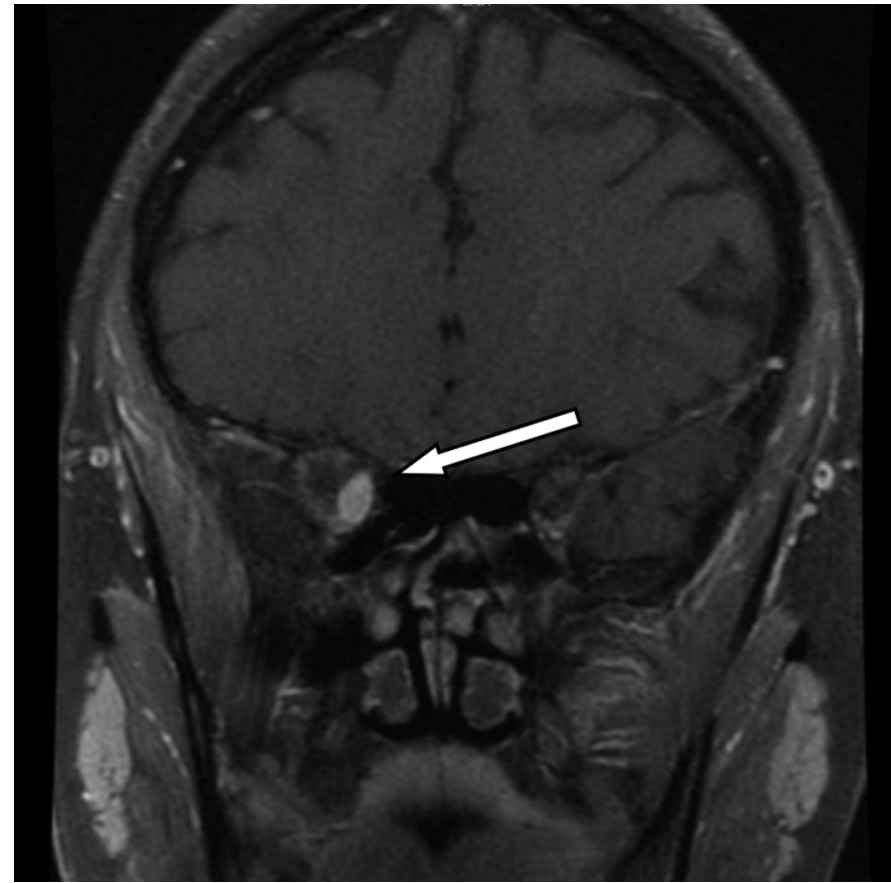

Figure 1. C) Coronal fat-suppressed, contrast-enhanced T1, arrow: Right medial rectus muscle enhances contrast and pushes the surrounding fatty tissue

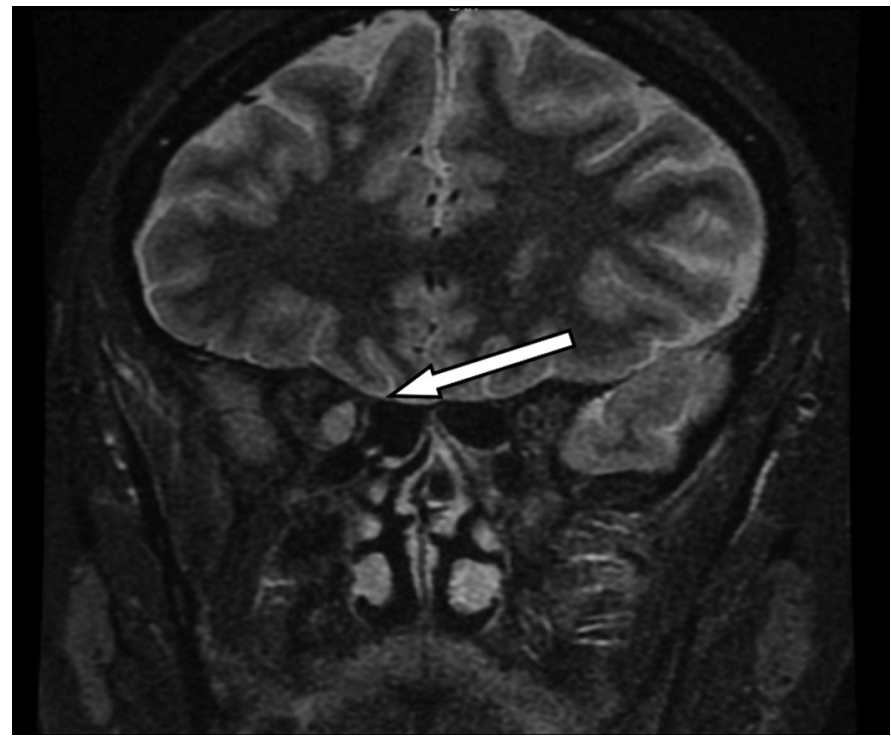

Figure 1. D) Coronal T2, arrow: Hypertrophic iso-hyperintense right medial rectus muscle. Surrounding fatty tissue is suppressed. No congestion in superior ophthalmic vein.

can also be used as maintenance and/or prophylactic treatment. Infliximab and radiotherapy can be used in unresponsive patients (5). Recurrence is frequent. In summary, the differential diagnosis of a patient presenting with isolated extraocular muscle palsy can be challenging. Steroid-responsive idiopathic orbital myositis should be kept in mind in conditions mimicking sixth nerve palsy. 


\section{Ethics}

Informed Consent: Informed consent was obtained from the patient.

Peer-review: Internally peer-reviewed.

\section{Authorship Contribution}

Surgical and Medical Practices: Z.E.B., S.A.B., O.Ö., S.Ş., C.D., H.H.S., H.D.A., Concept: Z.E.B., S.A.B., Design: Z.E.B., S.A.B., Data Collection or Processing: Z.E.B., S.A.B., O.Ö., S.Ş., C.D., H.H.S., H.D.A., Analysis or Interpretation: Z.E.B., S.A.B., O.Ö., S.Ş., C.D., H.H.S., H.D.A., Literature Search: Z.E.B., O.Ö., S.Ş., H.D.A., Writing: Z.E.B., S.A.B.

Conflict of Interest: No conflict of interest was declared by the authors.

Financial Disclosure: The authors declared that this study has received no financial support.

\section{References}

1. Skorin L Jr, English RF. Orbital myositis. J Am Osteopath Assoc 2014;114:135.

2. Pakdaman MN, Sepahdari AR, Elkhamary SM. Orbital inflammatory disease: Pictorial review and differential diagnosis. World J Radiol 2014;6:106-115.

3. Albu CV, Cătălin B, Zaharia C. A rare case of ocular myositis. Curr Health Sci J 2014;40:71-74.

4. Schoser BG. Ocular myositis: diagnostic assessment, differential diagnoses, and therapy of a rare muscle disease - five new cases and review. Clin Ophthalmol 2007;1:37-42.

5. Garrity JA, Coleman AW, Matteson EL, Eggenberger ER, Waitzman DM. Treatment of recalcitrant idiopathic orbital inflammation (chronic orbital myositis) with infliximab. Am J Ophthalmol 2004;138:925-930. 